\title{
Odnosi s javnošću u hrvatskim neprofitnim organizacijama na primjeru udruga osoba s invaliditetom
}

\section{IVANA KUČINA}

Sveučilište VERN', Zagreb

dr. sc. KREŠIMIR DABO

Edward Bernays Visoka škola za komunikacijski menadžment, Zagreb

\section{SAŽETAK}

U Hrvatskoj se razvoj društveno odgovornog ponašanja odvija vrlo sporo. Stoga je glavni cilj neprofitnih organizacija iznaći rješenja za socijalne probleme koje državne strukture nisu pravovremeno detektirale, dok je njihova misija podrška društvu (uglavnom marginalnim skupinama), jačanju humanosti i volonterstva i podizanju svijesti javnosti o društveno relevantnim pitanjima. Ovaj rad bavi se odnosima s javnošću u neprofitnim organizacijama na primjeru udruga osoba s invaliditetom. Cilj rada je definirati odnose s javnošću, objasniti što su to neprofitne organizacije i udruge osoba $s$ invaliditetom u Hrvatskoj te analizirati odnose s javnošću u hrvatskim udrugama osoba $s$ invaliditetom na temelju ankete. Rad je podijeljen u dva dijela. Prvi dio daje teoretski pregled odnosa s javnošću u neprofitnim organizacijama, definira što su to udruge osoba s invaliditetom u Hrvatskoj te pruža teorijski i pravni okvir. Drugi dio je istraživanje i sastoji se od prikaza stavova i mišljenja zaposlenika o odnosima $\mathrm{s}$ javnošću u udrugama osoba s invaliditetom i analize dobivenih podataka putem ankete.

Ključne riječi: udruge osoba s invaliditetom, neprofitna organizacija, odnosi s javnošću, odnosi s medijima 


\section{Uvod}

Odnosi s javnošću su komunikacijska aktivnost koja je postala nezamjenjiv dio menadžmenta svih organizacija: profitnih, neprofitnih, privatnih, javnih, vladinih ili nevladinih, radi stvaranja pozitivnog imidža organizacije $u$ javnosti. Udruge osoba s invaliditetom zakonom o udrugama ${ }^{1}$ definirane su kao neprofitne organizacije koje ne postoje zbog profita, već djeluju u korist svojih članova. Cilj je rada definirati i analizirati odnose s javnošću u neprofitnom sektoru na primjeru udruga osoba s invaliditetom. U radu će se definirati specifičnosti odnosa s javnošću u neprofitnom sektoru, predstaviti udruge osoba s invaliditetom u Hrvatskoj, analizirati odnosi s javnošću u udrugama osoba s invaliditetom, anketnim upitnikom analizirati stavovi i mišljenja o odnosima s javnošću udruga osoba s invaliditetom te predložiti smjernice za poboljšanje. Za teorijski dio rada korištena je relevantna literatura s područja udruga osoba s invaliditetom i odnosa s javnošću, zakoni i registri neprofitnih organizacija koji su dostupni javnosti te relevantna istraživanja. Provedeno je kvantitativno istraživanje na prigodnom uzorku udruga osoba s invaliditetom u Republici Hrvatskoj, uz korištenje standardne tehnike anketnog ispitivanja, utemeljene na strukturiranim pitanjima. Kroz rad će se definirati pojmovi neprofitnog sektora, udruga osoba s invaliditetom i odnosa s javnošću. Rad je strukturiran u osam poglavlja. Prvo poglavlje je Uvod. U drugom poglavlju obrađeni su odnosi s javnošću kao dio redovnog poslovanja udruga, a kroz kratak prikaz povijesti i definicije objašnjen je značaj odnosa s javnošću u neprofitnom sektoru. U trećem poglavlju prikazan je zakonodavni okvir koji prati osnivanje udruga i njihovu strukturu. Također, pojašnjeno je što udruge osoba s invaliditetom pružaju svojim članovima te njihova važnost za lokalnu zajednicu. U četvrtom poglavlju analizirana je uloga odnosa s javnošću u udrugama osoba s invaliditetom. U petom i šestom poglavlju predstavljen je istraživački problem i metodologija istraživanje te prikazana analiza anketnih upitnika. U raspravi su dane preporuke za poboljšanje. U zadnjem poglavlju, Zaključku, sažeti su najvažniji rezultati istraživanja i hipoteze iznesene u radu koje mogu poslužiti kao daljnje smjernice za istraživanja i rad vezan uz navedenu problematiku.

\section{Odnosi s javnošću u neprofitnom sektoru}

Odnosi s javnošću komunikacijska su aktivnost koja se kolokvijalnoj komunikaciji najčešće naziva PR-om, što je skraćenica od engl. public relations. S obzirom na to da su odnosi s javnošću relativno mlada profesija u stručnoj literaturi nailazimo na mnogo definicija. Često citirana definicija Public Relation Newsa, koju spominje i Tkalac Verčić (2015), tumači kako je to funkcija menadžmenta namijenjena procjenjivanju mišljenja javnosti, identificiranju poslovanja osoba ili organizacija koje imaju javni značaj, a uz to odnosi s javnošću planiraju i provode akcijski program usmjeren na povezivanje organizacije i njezinih javnosti. U rujnu 2019. Upravni odbor Međunarodnog udruženja za odnose s javnošću - IPRA, usvojio je novu definiciju odnosa s javnošću u Erevanu u Armeniji. Definicija prevedena na hrvatski jezik glasi: „Odnosi s javnošću upravljačka su funkcija koja uključuje donosioce strateških odluka u organizaciji, sa zadatkom izgradnje dugoročnih odnosa i interesa između organizacije i njenih ključnih javnosti - odnosa zasnovanih na međusobnom informiranju kroz pouzdane i etične komunikacijske metode. “2

U Hrvatskoj počeci razvoja odnosa s javnošću počinju šezdesetih godina 20. stoljeća, kada je otvoreno radno mjesto menadžera za odnose s javnošću u hotelu Esplanade 1964. 1994. je osnovana Hrvatska udruga za odnose s javnošću, a unazad 20-ak godina odnosi s javnošću prepoznati su i razvijaju se kao samostalna struka. Osnivanjem Hrvatske udruge komunikacijskih agencija 2010. napravljen je velik iskorak u promicanju i razvoju struke. Danas odnosi s javnošću imaju sve veću ulogu i u praksi i u

1 Zakon o udrugama, Narodne novine 74/2014 (27. kolovoza 2020.)

2 https://www.ipra.org/member-services/pr-definition/ (27. kolovoza 2020.) 
znanosti. Zadnjih 15-ak godina sve veći je trend uvođenja posebnih odjela za odnose s javnošću te se struka razvija kroz obrazovanje stručnjaka u sklopu akademskog sustava (Tkalac Verčič, 2015.). Za razvoj i poboljšanje statusa odnosa s javnošću u svijetu, ali i u Hrvatskoj, zaslužne su profesionalne udruge koje su stručnjaci osnovali kao neprofitne organizacije. Tako Božo Skoko (2009) pojašnjava kako se odnosi s javnošću u neprofitnom sektoru razvijaju unatrag nekoliko posljednjih godina, te kako su u neprofitnom sektoru aktivnosti odnosa s javnošću usmjerene, između ostalog, na stvaranje potpore za poslanje udruge, razvijanje komunikacijskih kanala s javnostima kojima udruga služi, stvaranje i održavanje odnosa s donatorima, poticanje javnih politika koje bi bile od pomoći udruzi i njezinom djelovanju te na informiranje i motiviranje ključnih javnosti za usmjerenost i posvećivanje ciljevima udruge. Autori knjige „Osnove marketinga i menadžmenta neprofitnih organizacija” pojašnjavaju marketing neprofitnih organizacija kao skup različitih aktivnosti kojima se kreira i poboljšava planiranje, realizacija i komuniciranje uloge i djelovanja organizacija koje ostvaruju neki određeni javni interes, ali im temeljni cilj postojanja nije ostvarivanje profita (Alfirević i sur., 2013). U tom smislu Skoko (2009) dodatno pojašnjava kako neprofitne organizacije moraju paziti na upravljanje i ugled, s obzirom na to kako dobrim imidžem neprofitne organizacije stječu povjerenje korisnika, ali i privlače donatore, sponzore i volontere te prikupljaju potrebna sredstava za svoje djelovanje. Skoko dodatno navodi kako je najznačajnija karakteristika neprofitnog sektora njegova ovisnost o mišljenju javnosti, odnosno, svojevrsna ovisnost o javnom ugledu pa je samim time uloga odnosa s javnošću iznimno važna. Uz to, dodaje Skoko, imidž neprofitnih organizacija važan je i zbog financija, odnosno stjecanja potpore javnosti za programe i projekte, a uz to, odnosi s javnošću u neprofitnom sektoru uspostavljaju, ali i održavaju odnose koji su važni da bi se organizacija pozicionirala, ali i osigurala sredstva koja su potrebna za realizaciju svoje misije. U svom radu Radalj (2018) tvrdi da se organizacije u neprofitnom sektoru obraćaju velikom broju javnosti, od članova, korisnika, lokalne zajednice i društva u državi u kojoj djeluje, pa sve do javnosti međunarodnih organizacija koje se bave istim pitanjima.

U današnjem, suvremenom okruženju, kada je internet postao ne samo izvor informacija, nego i prostor u kojem se korisnici upoznaju, povezuju i komuniciraju, Grbavac i Grbavac (2014) otvaraju važnu temu povezanu sa smjerom razvoja društvenih mreža. Neprofitni sektor, posebno udruge osoba s invaliditetom danas imaju značajnu ulogu u razvoju lokalne sredine i pružanju krajnjim korisnicima specijaliziranih usluga. Upravo iz tih individualnih potreba postoje specifičnosti odnosa s javnošću u tim organizacijama. Udruge su ovisne o stvaranju pozitivnog imidža prema svojim članovima, ali i donatorima koji odlučuju koje će udruge i na koji način financirati. Također, većina udruga nema dovoljno sredstava za marketinške aktivnosti odnosa s javnošću te taj dio odrađuju svi zaposlenici pomalo. Broj udruga osoba s invaliditetom poprilično je velik u Republici Hrvatskoj, međutim, sve organizacije danas mogu biti dio javne sfere zbog lakog pristupa novim tehnologijama. Dolaskom interneta omogućena je veća vidljivost te se pojednostavljuje mogućnost komuniciranja sa svim dionicima. Iako je internet već sam po sebi neprofitnim organizacijama donio mnogo novih mogućnosti, smatra se kako su društveni mediji otvorili još više novih mogućnosti za komunikaciju s javnošću. Tradicionalni mediji (novine, radio, TV, letci, plakati i dr.) predstavljaju tradicionalan način informiranja. Društveni mediji (društvene mreže, blogovi, forumi) koriste nove tehnologije za prijenos informacija. Društvene mreže (Facebook, Instagram i Twitter) u fokusu su neprofitnog sektora jer se radi o besplatno dostupnim alatima koji su i dobra nadopuna mrežnim stranicama. (Hajoš, Skoko, 2009.) Sadržaj koji je dostupan i koji korisnici kreiraju na internetu ima sve važniju ulogu u komunikaciji posebice u odnosima s javnošću. Cijeli koncept dosadašnjeg rada mijenja se iz dana u dan, prilagođavajući se novim trendovima. Danas u Republici Hrvatskoj 92,3 \% stanovnika koristi internet, od čega 50,6 \% ima aktivan profil na Facebooku. ${ }^{3}$

3 Statistika dostupna do siječnja 2020. http://www.internetworldstats.com/europa.htm\#hr (27. kolovoza 2020.) 


\section{Udruge osoba s invaliditetom u Hrvatskoj}

U Republici Hrvatskoj u 19. stoljeću bilježi se razvoj dobrotvornih društava koja su pretežno usmjerena na pomoć siromašnim obiteljima, posebno siromašnoj djeci, a većina tih društava bila je utemeljena na vjerskoj osnovi. Jedan od mnogih primjera je humanitarno društvo „Dobrotvor” koje je osnovano 1877. godine na inicijativu Đure Deželića radi pomoći siromašnoj zagrebačkoj, ali i ostaloj djeci. Godine 1893. Centar za odgoj i obrazovanje Vinko Bek osniva humanitarno karitativno „Društvo sv. Vida za podupiranje slijepaca”. Prva udruga osoba s invaliditetom osnovana u Republici Hrvatskoj je Hrvatski savez slijepih osnovan 1946. godine. U narednim godinama prepoznata je važnost osnivanja udruga prema vrsti oštećenja (Puljiz, 2005). Kao posljedica rata i dubokih promjena tijekom 1990-ih godina u Hrvatskoj se pojavilo ekspandirajuće siromaštvo te se veliki broj građana suočio s problemima preživljavanja i zadovoljavanja najosnovnijih potreba, u čemu je u ratnom i poslijeratnom vremenu (do 1997.) važnu ulogu igrala građanska solidarnost i (međunarodna) humanitarna pomoć. ${ }^{4}$ Vrijednost nevladinih humanitarnih organizacija u tom se razdoblju očitovala kroz sposobnost angažiranja velikog broja volontera koji bi mogli provesti programe i projekte za opće dobro. Prema trenutno važećem zakonu o udrugama definirane su organizacije koje djeluju u Republici Hrvatskoj, a imaju status neprofitne pravne osobe (udruge, zaklade, fundacije, te organizacije koje na temelju javnih ovlasti propisanih zakonom prikupljaju humanitarnu pomoć), vjerske zajednice i profitne pravne i fizičke osobe. ${ }^{5}$ Status neprofitne pravne osobe označava pripadnost neprofitnom sektoru. Neprofitni sektor označava skup organizacija koje su: formalno konstituirane, nevladine $\mathrm{u}$ osnovnoj strukturi, samoupravljačke, neprofitno distribuirane, te dobrovoljne do neke smislene mjere (Lester i Anheier, 1992). Neprofitne organizacije ne postoje zbog ostvarivanja profita, već djeluju primarno radi neke opće koristi u društvu ili podmiruju neke potrebe koje nije moguće efikasno podmiriti preko tržišta, a važne su za razvoj društva (Bežovan, 1995). Najčešći oblik registracije neprofitne organizacije je udruga koja se prilikom upisa u Registar udruga mora i klasificirati prema djelatnosti i ciljnoj skupini. Udruge osoba s invaliditetom klasificirane su prema socijalnoj djelatnosti i ciljnoj skupini osoba s invaliditetom. ${ }^{6}$ Također, prilikom osnivanja, neprofitna organizacija se upisuje u Registar neprofitnih organizacija pri Ministarstvu financija. ${ }^{7} \mathrm{Na}$ dan 27 . kolovoza 2020. u Registru udruga registrirano je 4.917 aktivnih udruga u području djelovanja socijalne djelatnosti, ${ }^{8}$ a u Registru neprofitnih organizacija registrirano je 44.558 udruga. ${ }^{9}$ Udruge su značajan segment neprofitnog sektora u Republici Hrvatskoj. Struktura udruga identična je svjetskoj uz minimalne specifičnosti, te su organizirane na lokalnoj, državnoj i međunarodnoj razini. Na lokalnoj razini korisnici su organizirani u „čiste“ ili „mješovite“. „Čiste“ udruge okupljaju korisnike prema ciljanim ili specifičnim oštećenjima (slijepi, gluhi, cerebralna paraliza, distrofija, intelektualne poteškoće i dr.). Mješovite udruge osnovane su u manjim sredinama, a okupljaju korisnike sa svim vrstama oštećenja. $\mathrm{Na}$ nacionalnoj razini udruge s istim vrstama oštećenja okupljaju se u nacionalne saveze udruga (Savez društava distrofičara Hrvatske, Hrvatski savez cerebralne i dječje paralize, Hrvatski savez slijepih, Hrvatski savez udruga osoba s tjelesnim invaliditetom i dr.). „Krovna organizacija osoba s invaliditetom po vrstama invaliditeta i roditelja ili skrbnika osoba s invaliditetom koje se ne mogu same zastupati je Zajednica saveza osoba s invaliditetom Hrvatske - SOIH. Mrežu SOIH-a čini 16 nacionalnih saveza i OSVIT, kao mreže zaštitnih radionica Hrvatske, koja okuplja preko 250 lokalnih

Program borbe protiv siromaštva i isključenosti u Hrvatskoj, 2001. (27. kolovoza 2020.)

Zakon o udrugama, Narodne novine 74/2014 (27. kolovoza 2020.)

Registar udruga u RH, Ministarstvo uprave, https://registri.uprava.hr/\#! udruge_rQMBAAEAAAAA3gQBAAABAgAAAAGA-

474KAAAAAQEAAAABAgAAAAAAAAABAQFvaeICAfSBBg (27. kolovoza 2020.)

Registar neprofitnih organizacija, Ministarstvo financija, https://banovac.mfin.hr/rnoprt/ (27. kolovoza 2020.)

8 Registar udruga u RH, Ministarstvo uprave, https://registri.uprava.hr/\#!udrugerQMBAAEAAAAA3gQBAAABAgAAAAGA-

474KAAAAAQEAAAABAgAAAAAAAAABAQFvaeICAfSBBg (27. kolovoza 2020.)

9 Registar neprofitnih organizacija, Ministarstvo financija, https://banovac.mfin.hr/rnoprt/ (27. kolovoza 2020.) 
udruga osoba svih vrsta invaliditeta u cijeloj Republici Hrvatskoj“. ${ }^{10}$ Kako navode Narodne novine (26/2015), udruge osoba s invaliditetom u Republici Hrvatskoj financiraju se iz članarina, donacija građana, ali i od lokalnih, nacionalnih i međunarodnih davatelja financijskih sredstava, i to putem javnih natječaja. S obzirom na iznimna financijska izdvajanja, ali i visoke potrebe za transparentnosti te odgovornosti pri trošenju, odnosno upravljanju sredstvima poreznih obveznika, Vlada Republike Hrvatske donijela je, na temelju Zakona o udrugama Uredbu o kriterijima, mjerilima i postupcima financiranja i ugovaranja programa i projekata od interesa za opće dobro koje provode udruge. Uredba određuje mjerila koja moraju ispunjavati udruge koje namjeravaju koristiti sredstva iz javnih izvora za provedbu programa i projekata od interesa za opće dobro. Udruga koja koristi sredstva iz javnih izvora mora biti upisana u Registar udruga i Registar neprofitnih organizacija, statutom mora biti definirana za obavljanje djelatnosti koje se financiraju i kojima promiče uvjerenja i ciljeve koji nisu u suprotnosti s Ustavom i zakonom. Nadalje, mora uredno ispunjavati obveze iz svih prethodno sklopljenih ugovora o financiranju iz javnih izvora, mora uredno plaćati doprinose i poreze te ostala davanja prema državnom proračunu i proračunima jedinica lokalne samouprave, ne smije se protiv udruge, odnosno osobe ovlaštene za zastupanje udruge i voditelja programa ili projekta voditi kazneni postupak i ne smije biti pravomoćno osuđena za prekršaj ili kazneno djelo iz članka 48. Uredbe, mora imati organizacijskologističke i ljudske kapacitete za provedbu projekta i transparentno upravljanje javnim sredstvima, te ispunjavati dodatne uvjeti koje propiše davatelj financijskih sredstava. ${ }^{11}$ Kako navodi Zajednica osoba s invaliditetom Hrvatske, unatoč dostupnim sredstvima na lokalnoj, nacionalnoj i međunarodnoj razini, mnogo udruga nema dovoljne organizacijske i ljudske kapacitet za upravljanje javnim sredstvima u provođenju projekata ili programa od javnog interesa. Naglašavaju kako tome u prilog govori i činjenica da je u Registru udruga aktivno 3.784 udruga čije je područje djelovanja socijalna skrb, međutim na području Republike Hrvatske aktivno s korisnicima radi oko 250 udruga. ${ }^{12}$

\section{Uloga odnosa s javnošću u udrugama osoba s invaliditetom}

Uloga odnosa s javnošću unutar udruga osoba s invaliditetom najčešće počinje neplanirano, no od iznimne je važnosti za organizaciju. Netko od zaposlenika preuzima zaduženje za odgovaranje na pristigle dopise i elektroničku poštu, telefonske pozive, predstavljanje aktivnosti provedenih projekata, pripremu tekstova za mrežne objave, pripremanje godišnjeg izvještaja i sl. Neprofitne organizacije su iznimno ovisne o mišljenju javnosti, naglašava Skoko (2006) te ovise o javnoj podršci. Zbog toga, pojašnjava autor, njihovi odnosi s javnošću imaju iznimnu ulogu u predstavljanju organizacije, prezentiranju djelovanja te u kreiranju javnog povjerenja. Skoko tumači kako su one često izložene utjecajima različitih društvenih, političkih i ekonomskih trendova, koji podrazumijevaju detaljno upravljanje komunikacijom te učinkovite odnose s javnošću. Nadalje, Hajoš i Skoko (2009) navode kako je imidž koji udruga ima u javnosti jako važan, i to iz nekoliko razloga, od kojih su najvažniji financiranje te pridobivanje potpore javnosti za programe i projekte. To znači, tumače autori, da su u svojoj komunikaciji s javnošću fokusirane i na natjecanja za donacije i različite državne poticaje. Stoga odnosi s javnošću u neprofitnom sektoru uspostavljaju i održavaju odnose koji su nužni da bi organizacija osigurala vlastitu funkcionalnost, samostalnost, ali i sredstva potrebna za ostvarivanje svoje misije, zaključuju autori. S druge strane, Tomić (2016) dodatno pojašnjava kako je položaj i uloga odnosa s javnošću u neprofitnim organizacijama različita od organizacije do organizacije jer na mjesto i ulogu svakodnevno utječu aktivnosti kojima se organizacije bave, kao i broj djelatnika, te komunikacijski potencijal zaposlenika koji rade s javnošću. Uloga koju je definirao Tomić primjenjiva je i na udruge osoba s invaliditetom uz naglasak na geografski položaj udruge.

10 Zajednica saveza osoba s invaliditetom Hrvatske - SOIH, http://www.soih.hr/soih-o-nama (27. kolovoza 2020.)

11 Narodne novine 26/2015 (27. kolovoza 2020.)

12 http://www.soih.hr/soih-o-nama (27. kolovoza 2020.) 
Pregledom stručne literature najbolji opis uloge odnosa s javnošću daje Broom (2010) navodeći njihovih pet ključnih ciljeva: „1. Definirati ili brendirati organizaciju, odnosno zaštiti njezin ugled, 2. Stvoriti komunikacijske kanale za komuniciranje s klijentima, 3. Stvoriti i održavati povoljnu klimu za prikupljanje sredstava, 4. Poduprijeti razvoj i opstanak javne politike koja je naklonjena misiji organizacije, 5. Informirati i motivirati ključne činitelje organizacije da produktivno podupiru njezine ciljeve“. Svaka udruga ima drugačiji pristup odnosima s javnošću jer imaju donekle drugačije javnosti, no pristup i naglasak na određena područja je jednak za sve. Tomić (2016) daje pregled mogućih aktivnosti u odnosima s javnošću:

1. Komunikacija s članovima, vladom i ostalim ciljnim skupinama.

2. Pronalazak novih članova.

3. Kreiranje kampanja te organizacija javnih događanja.

4. Izrada vlastitih komunikacijskih kanala.

5. Uključivanje osoba iz javnog života.

6. Lobiranje - najčešće se provodi na razini države, ali i lokalne vlasti.

7. Parničenje - udruge sudskim procesima nastoje utjecati na donošenje odluka koje su povoljne za njih.

8. Demonstracije/prosvjedi - sredstvo za pridobivanje potpore javnosti.

9. Bojkoti.

10. Suradnja s kompanijama na rješavanju određenih problema.

11. Rad s vanjskim agencijama.

Unatoč tome što su ciljevi zajednički većini udruga, taktike i tehnike odnosa s javnošću razlikuju se od udruge do udruge. Važno je napomenuti da neke udruge imaju zaposlenog djelatnika koji se bavi odnosima s javnošću, dok druge nemaju. Udruge osoba s invaliditetom imaju tri glavna izvora prihoda: članarine, donacije pojedinaca i poslovnog sektora te projektno financiranje. Velik problem je što nisu sustavno financirane te se zbog nesigurnosti financiranja rijetke organizacije odlučuju na zapošljavanje stručnjaka. Najčešće su tehnike i alati u komunikaciji s javnošću popis medija i novinara (adrema), najava za medije, fotovijest, personalizirano pismo, priopćenje za javnost, konferencija za novinare, internetska konferencija, izjava za javnost, bilteni i godišnja izvješća o radu udruga.

\section{Istraživački problem i metodologija}

Udruge osoba s invaliditetom definirane su Zakonom o udrugama kao neprofitne organizacije koje ne postoje zbog profita, već djeluju u korist svojih članova. Udruge osoba s invaliditetom nisu sustavno financirane iz državnog ili lokalnog proračuna, već se za financiranje aktivnosti prijavljuju na otvorene natječaje. Uzroci nedostatnog sustavnog financiranja predstavljaju natječaji koji su programirani za ispunjavanje posebnih ciljeva i koji ne prepoznaju važnost financiranja osobe koja bi se unutar organizacije bavila samo odnosima s javnošću. Činjenica je da u udrugama osoba s invaliditetom svi rade sve poslove zbog manjka ljudskih kapaciteta i financijskih sredstava. Svrha je istraživanja analizirati odnose $s$ javnošću u neprofitnom sektoru na primjeru udruga osoba s invaliditetom te utvrditi stavove i mišljenja zaposlenika o odnosima s javnošću u neprofitnom sektoru na primjeru udruga osoba s invaliditetom, kako bi se razradili prijedlozi za razvoj odnosa s javnošću u udrugama osoba s invaliditetom. 
Ciljevi istraživanja su sljedeći:

1. Ustanoviti kojim se komunikacijskim kanalima i alatima koriste udruge osoba s invaliditetom te koriste li pri tome usluge vanjskog suradnika i/ili agencije za odnose s javnošću;

2. Utvrditi stavove i mišljenja zaposlenika udruga osoba s invaliditetom o odnosima s javnošću u neprofitnom sektoru i,

3. Definirati očekivanja zaposlenika udruga osoba s invaliditetom.

Istraživački zadaci anketnog upitnika su sljedeći:

1. U kojoj mjeri udruge osoba s invaliditetom koriste tehnike odnosa s javnošću u komunikaciji s javnostima?

2. Koliko su zaposlenici udruga informirani o aktivnostima i projektima udruge?

3. Kakva je percepcija zaposlenika u udrugama osoba s invaliditetom o odnosima s javnošću?

4. Koja je percepcija zaposlenika o komunikaciji udruga osoba s invaliditetom?

5. Koja su očekivanja zaposlenika udruga osoba s invaliditetom od odnosa s javnošću u neprofitnom sektoru?

Mjerni instrument istraživanja je anonimni online anketni upitnik, a izvor podataka je neposredno prikupljanje i analiziranje podataka. Uzorak ciljne populacije je prigodan i utvrđen prema udrugama članicama Zajednice saveza osoba s invaliditetom. Anketa je poslana putem elektroničke pošte krovne organizacije prema nacionalnim savezima te prema lokalnim udrugama osoba s invaliditetom. U istraživanje je bilo uključeno 50 udruga osoba s invaliditetom iz cijele Hrvatske. Istraživanje je provedeno od 12. do 17. prosinca 2017. Online anketa poslana je svim aktivnim udrugama osoba s invaliditetom na području Republike Hrvatske putem elektroničke pošte. Anketni upitnik je 12. prosinca upućen na 210 e-adresa, a do 17. prosinca vraćeno ih je 50.

\section{Analiza rezultata}

Istraživanje stavova i mišljenja udruga osoba s invaliditetom provedeno je metodom anonimne online ankete. Anketa se sastojala od unaprijed formuliranih pitanja putem kojih su prikupljana društveno-demografska obilježja ispitanika te stavovi i mišljenja o odnosima s javnošću udruga osoba s invaliditetom. Prilikom prikaza rezultata istraživanja korišteni su prikazi realnih brojeva i postotaka, te citati iz ankete. Analiza dobivenih rezultata istraživanja strukturirana je prema kategorijama istraživanja u anketi.

\subsection{Analiza prema osnovnim podacima udruga}

U okviru anketnog upitnika izrađena su pitanja koja pružaju osnovne informacije o udrugama osoba s invaliditetom poput godine osnivanja organizacije, geografskog područja djelovanja organizacije, broja projektnih prijedloga prijavljenih na javne natječaje u protekle tri godine i broja provedenih projektnih prijedloga u protekle tri godine. 
Slika 1. Odnos podataka godine osnivanja i broja prijavljenih i provedenih projekata

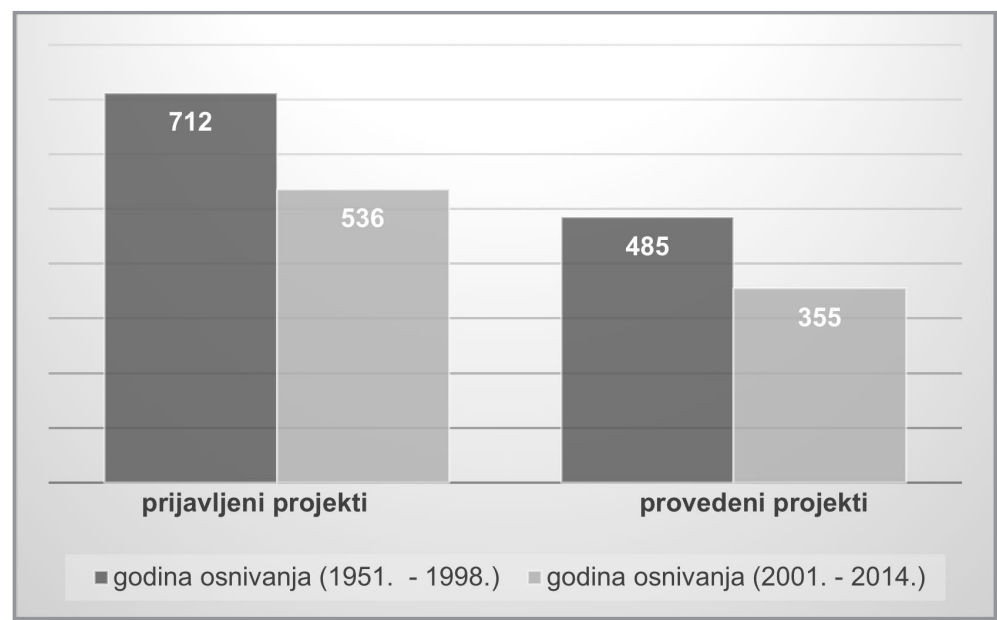

Izvor: rad autora

Na temelju prikupljenih podataka Slika 1. prikazuje odnos godine osnivanja organizacije te broja prijavljenih i broja provedenih projektnih prijedloga $\mathrm{u}$ prethodne tri godine iz kojih možemo zaključiti da udruge s većim iskustvom u radu s obzirom na godinu osnivanja prijavljuju i provode veći broj projektnih prijedloga od udruga s manjim iskustvom u radu.

Udruge osoba s invaliditetom prema registraciji djelatnosti prilikom upisa u Registar udruga, moraju se klasificirati prema geografskom području djelovanja na području Republike Hrvatske. Udruga može biti registrirana na cijelom području Republike Hrvatske, području jedne ili više županija te na području gradova i općina. 
Slika 2. Geografsko područje djelovanja

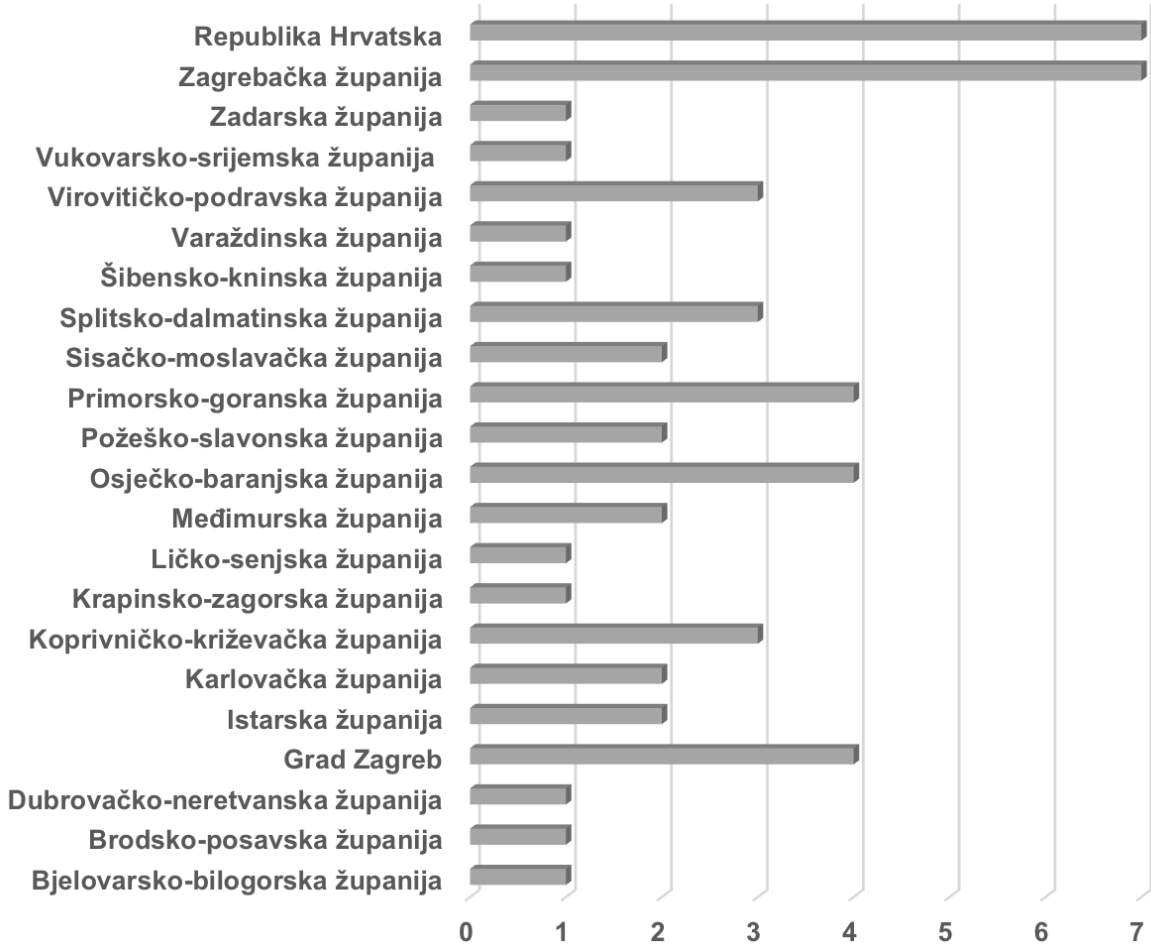

Izvor: rad autora

Slika 2. prikazuje područje rada udruga osoba s invaliditetom koje su sudjelovale u istraživanju iz čega proizlazi zaključak da udruge djeluju na regionalnim županijskim područjima zbog mogućnosti lakšeg okupljanja članstva i pružanja direktnih socijalnih usluga. Nekoliko udruga djeluje na čitavom području Republike Hrvatske zato što okupljaju članove s rijetkim bolestima.

\subsection{Analiza stavova i mišljenja zaposlenika}

Područje odnosa s javnošću u neprofitnom sektoru tek je u začetku razvoja, s obzirom na to da su se tek unazad 20 godina odnosi s javnošću počeli intenzivnije razvijati u profitnom sektoru na području Republike Hrvatske. Prema provedenom istraživanju Hrvatske udruge za odnose s javnošću o stanju struke odnosa s javnošću iz 2013., 48 \% zaposlenika uz poslove odnosa s javnošću obavlja i druge poslove. ${ }^{13} \mathrm{U}$ prvom setu pitanja dolazi se do stanja struke u udrugama osoba s invaliditetom koji je povezan s ciljem istraživanja 1: ustanoviti kojim se komunikacijskim kanalima i alatima koriste udruge osoba s invaliditetom te koriste li pri tome usluge vanjskog suradnika i/ili agencije za odnose s javnošću.

13 Istraživanje dostupno na http://www.huoj.hr/aktivnosti-udruge/provedeno-huoj-evo-istrazivanje-o-stanju-struke-odnosa-sjavnoscu-u-hrvatskoj-2013-hr3759 (27. kolovoza 2020.) 
Slika 3. Prikaz stanja struke u neprofitnom sektoru

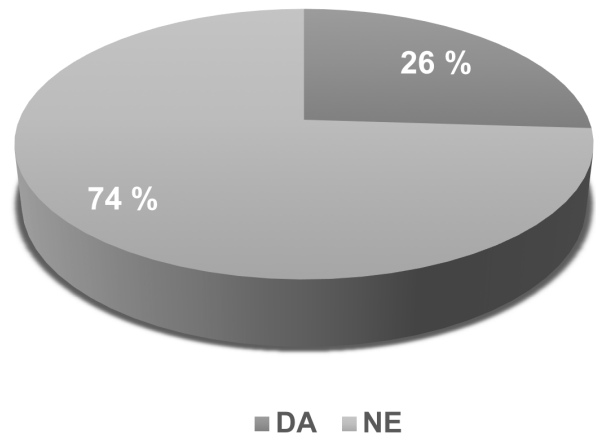

Izvor: rad autora

Od 2006. porastao je broj specijaliziranih odjela odnosa s javnošću u profitnom sektoru, što u neprofitnom sektoru još nije slučaj. Prema podacima iz Slike 3. vidljivo je kako samo $26 \%$ udruga ima zaposlenu osobu koja radi poslove iz područja odnosa s javnošću. Iz čega se može zaključiti kako potreba za takvim tipom stručnjaka još nije u potpunosti prepoznata u neprofitnom sektoru. Od ukupnog broja zaposlenih samo tri osobe imaju zvanje magistre komunikologije i novinara, a ujedno rade i kao voditelji projekata, što ide u prilog istraživanju koje navodi da $45 \%$ komunikacijskih stručnjaka dolazi iz redova novinara. ${ }^{14}$

Slika 4. Korištenje usluga vanjskog stručnjaka i/ili agencije

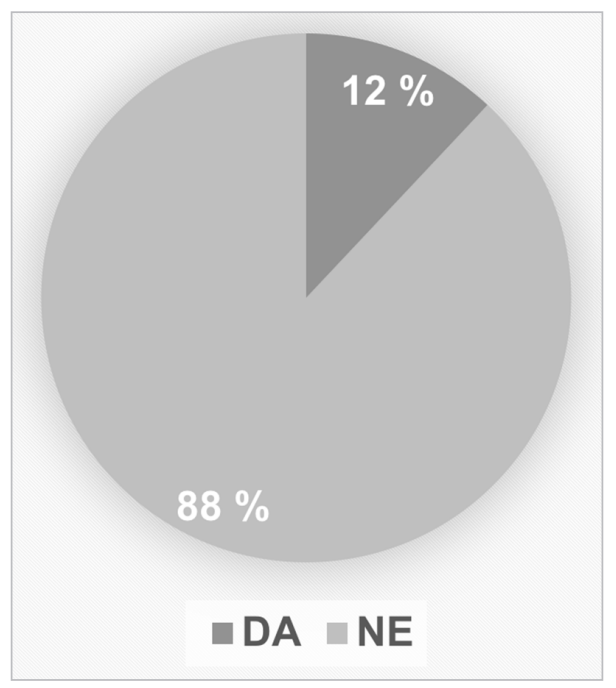

Izvor: rad autora

S obzirom na to da udruge osoba s invaliditetom ne prepoznaju dovoljno važnost odnosa s javnošću u radu udruga, prema Slici 4. vidljivo je kako udruge niti ne koriste usluge vanjskih stručnjaka iz

14 Istraživanje dostupno na http://www.huoj.hr/aktivnosti-udruge/provedeno-huoj-evo-istrazivanje-o-stanju-struke-odnosa-sjavnoscu-u-hrvatskoj-2013-hr3759 (27. kolovoza 2020.) 
područja odnosa s javnošću jer ne smatraju područje dovoljno relevantnim u poslovanju svojih organizacija. Važnost marketinga u neprofitnom sektoru je prepoznata, međutim, klasični principi često nisu primjenjivi i ovise o specifičnostima svake konkretne organizacije.

U sljedećem setu pitanja analizirat će se dobiveni podaci vezani uz istraživački cilj 2: utvrditi stavove i mišljenja zaposlenika udruga osoba s invaliditetom o odnosima s javnošću u neprofitnom sektoru. U okviru udruga osoba s invaliditetom slabo je prepoznata važnost odnosa s javnošću u stvaranju pozitivnog imidža udruga osoba s invaliditetom, pri čemu je $62 \%$ udruga suglasno s tezom kako su odnosi s javnošću važni, dok 36 \% udruga ne smatra važnim ulaganje u razvoj odnosa s javnošću u okviru udruge, što je vidljivo na slici 5.

\section{Slika 5. Stavovi i mišljenja udruga osoba s invaliditetom}

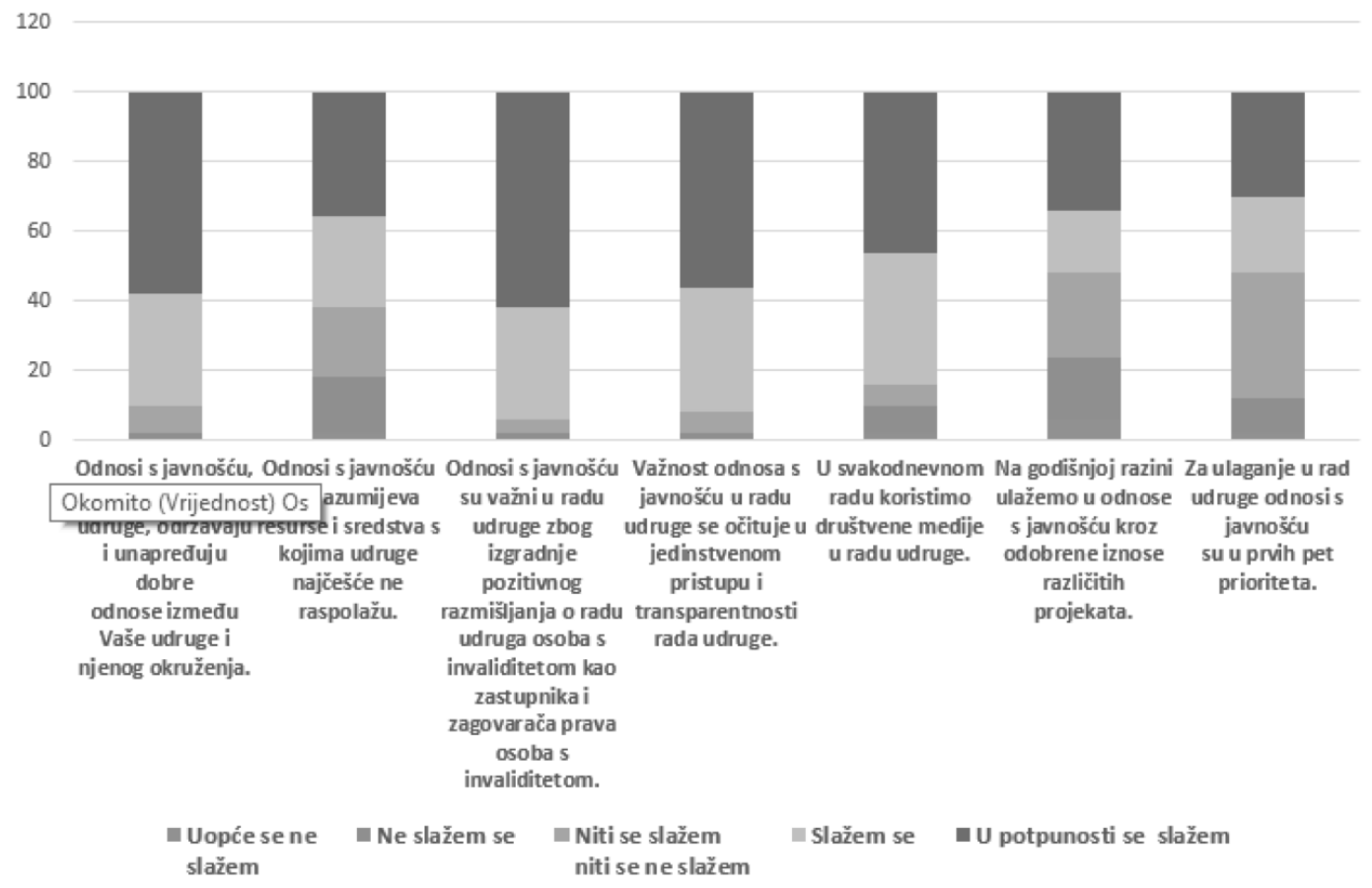

Izvor: rad autora

Plećaš (2016., prema Helmig i sur., 2004.; Bennett i Savani, 2004.) tvrdi da je važna prepreka neprofitnom sektoru činjenica što individualni donatori, kao i velike fondacije, često ne uviđaju značaj marketinga i doživljavaju ga kao nepotreban trošak. Fondovi su većinom ograničeni, pa organizacije moraju ciljano prikupljati sredstva za potrebe provođenja marketinških aktivnosti (2006., prema Pope, 2016.), što govori u prilog tezi Odnosi s javnošću podrazumijevaju resurse i sredstva s kojima udruge najčešće ne raspolažu, s kojom je $36 \%$ udruga u potpunosti, a $26 \%$ djelomično suglasno. Prema istraživanju $18 \%$ se slaže, a čak $34 \%$ se u potpunosti slaže s tezom Na godišnjoj razini ulažemo u odnose s javnošću kroz odobrene iznose različitih projekata. Najzastupljeniji komunikacijski alati su oni koji su besplatni ili koje se može financirati kroz odobrene projektne prijedloge. Na Slici 6. vidljivi su podaci da su internetske stranice, Facebook i Instagram najzastupljeniji profili u neprofitnom sektoru. 
Slika 6. Korištenje komunikacijskih alata u radu udruge

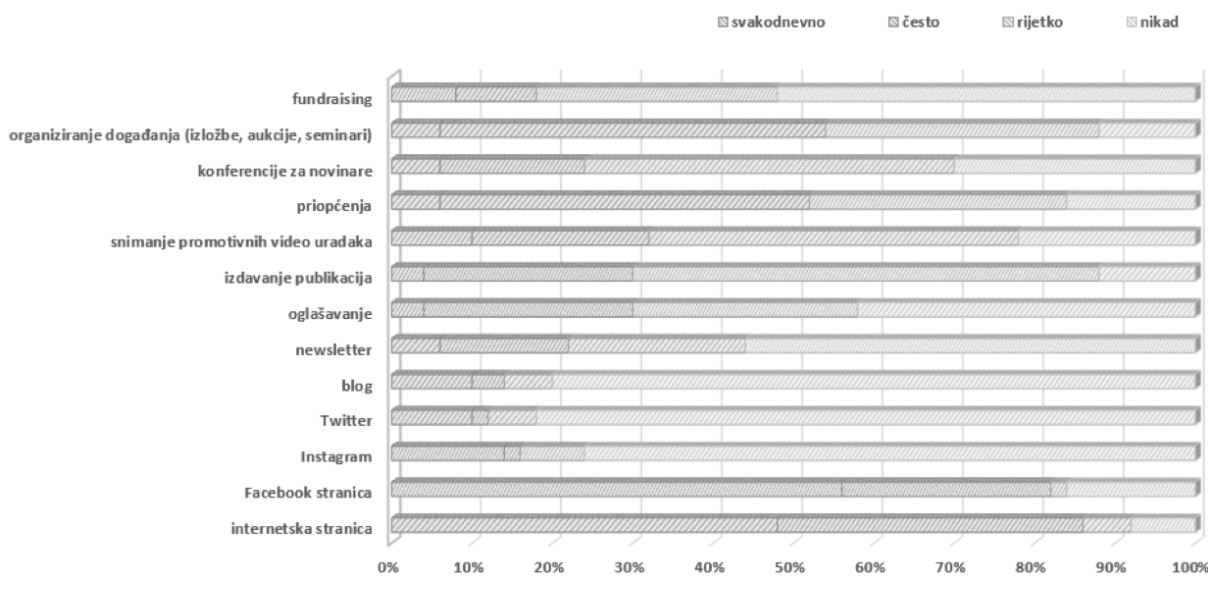

Izvor: rad autora

Glavni razlozi zašto udruge nikada ne koriste pojedine komunikacijske alate je nedostatak ljudskih i financijskih kapaciteta sredstava kojima bi se takve aktivnosti kontinuirano financirale. Udruge osoba s invaliditetom smatraju da područje odnosa s javnošću znači informiranost okoline, a zatim vidljivost i promicanje prava osoba koje udruga zastupa. Iz prezentiranih podataka vidljivo je da udruge osoba s invaliditetom krivo interpretiraju ulogu odnosa s javnošću u neprofitnom sektoru.

Zadnji set pitanja vezan je uz cilj istraživanja 3: definirati očekivanja zaposlenika udruga osoba s invaliditetom. U okviru istraživanja jedan od najzastupljenijih prijedloga poboljšanja odnosa $s$ javnošću u udruzi je zapošljavanje osobe odgovorne za provedbu aktivnosti u području odnosa s javnošću, na što se nadovezuje i druga najvažnija aktivnost, a to je osiguravanje kontinuiranih financijskih sredstava za zapošljavanje stručnjaka. Na trećem i četvrtom mjestu nalazi se povećanje korištenja komunikacijskih alata i dodatne edukacije postojećih zaposlenika.

\section{Rasprava}

Pregledom stručne literature te analizom dobivenih podataka iz anketnog upitnika, može se zaključiti da je najvažnije educirati članove izvršnih i upravnih odbora o ulozi odnosa s javnošću $\mathrm{u}$ neprofitnom sektoru, a posebno u udrugama osoba s invaliditetom koje pružaju socijalne usluge osobama s invaliditetom. Udruge osoba s invaliditetom nisu sustavno financirane, već plaće ključnih zaposlenika (vozači, rehabilitatori, radni terapeuti, osobni asistenti i sl.) ovise o projektnom financiranju i donacijama. S obzirom na sve veće probleme i izazove koji ih svakodnevno okružuju, teško će se odlučiti za zapošljavanje osobe koja će raditi poslove odnosa s javnošću unatoč što su svjesni prednosti. U skladu s tom činjenicom predlaže se da Hrvatska udruga za odnose s javnošću kao krovna organizacija stručnjaka odnosa s javnošću osmisli „program podrške neprofitnom sektoru“ kroz povezivanje stručnjaka/agencija s neprofitnim sektorom/udrugama na određenom geografskom području u vidu stručne podrške za osmišljavanja komunikacijskih strategija, odnosa s medijima, javne kampanje i edukacije članova organizacija. Posljednjih godina pojavljuje se sve više stručne literature za primjenu odnosa s javnošću, no u svemu tome nedostaje „priručnik“ koji će dati konkretne alate, tj. gotove šprance, koje bi udruge mogle jednostavno i odmah primijeniti u radu. 


\section{Zaključak}

Cilj rada bio je analizirati odnose s javnošću na primjeru udruga osoba s invaliditetom. Kroz anketni upitnik analizirano je stanje u udrugama osoba s invaliditetom, koje komunikacijske kanale koriste i koliko često te koriste li usluge vanjskog stručnjaka i/ili agencije koje obavljaju poslove odnosa $s$ javnošću. Analizirao se stav i mišljenje zaposlenika o odnosima s javnošću i dobiveni su prijedlozi za njihovo poboljšanje. U istraživanju je korištena metoda anonimne online ankete. Anketa se sastojala od unaprijed formuliranih pitanja. Analizom ankete prikupljeni su društveno-demografski podaci sudionika te stavovi i mišljenja o odnosima s javnošću u udrugama osoba s invaliditetom. Uzorak ciljne populacije utvrđen je prema popisu članica krovne organizacije udruga osoba s invaliditetom Zajednice saveza osoba s invaliditetom Hrvatske. Anketa je udrugama proslijeđena putem elektroničke pošte.

U radu su postavljena tri istraživačka cilja. Prvi cilj bio je ustanoviti kojim se komunikacijskim kanalima i alatima koriste udruge osoba s invaliditetom te koriste li pri tome usluge vanjskog suradnika $\mathrm{i} / \mathrm{ili}$ agencije za odnose s javnošću. Prema dobivenim podacima vidljivo je da se udruge osoba s invaliditetom najčešće koriste besplatnim komunikacijskim kanalima kao što su internetske stranice i Facebook profil te da ne koriste vanjske stručnjake. Drugi istraživački cilj bio je utvrditi stavove i mišljenja zaposlenika udruga osoba s invaliditetom o odnosima s javnošću u neprofitnom sektoru. Zaposlenici su slabo prepoznali važnost odnosa s javnošću u radu, a posebno u stvaranju imidža udruge. Smatraju da je područje odnosa s javnošću u udrugama ključno za informiranje okoline, zatim vidljivosti i promicanju prava osoba koje udruga zastupa. Nadalje, vidljivo je da krivo interpretiraju ulogu odnosa s javnošću u neprofitnom sektoru. U trećem istraživačkom cilju definirana su očekivanja zaposlenika udruga osoba $\mathrm{s}$ invaliditetom. Unatoč krivo interpretiranju uloge u odnosima s javnošću jedan od najzastupljenijih prijedloga poboljšanja odnosa $s$ javnošću u udruzi je zapošljavanje osobe odgovorne za provedbu aktivnosti u području odnosa s javnošću. Na drugom mjestu je osiguravanje kontinuiranih financijskih sredstava za zapošljavanje stručnjaka, dok se na trećem i četvrtom mjestu nalazi povećanje korištenja komunikacijskih alata i dodatne edukacije postojećih zaposlenika.

Rezultati istraživanja i dostupna literatura pokazuju da su odnosi s javnošću mlada struka u Republici Hrvatskoj. Udruge osoba s invaliditetom nisu sustavno financirane iz državnog ili lokalnog proračuna, već se za financiranje aktivnosti prijavljuju na otvorene natječaje. Upravo iz toga razloga radna mjesta su nesigurna i stručnjaci se teško odlučuju za dolazak i ostanak. Također, nedostatak sustavnog financiranja su natječaji koji su programirani za ispunjavanje posebnih ciljeva i koji ne prepoznaju važnost financiranja osobe koja bi se unutar organizacije bavila samo odnosima s javnošću. Činjenica je da u udrugama osoba s invaliditetom svi rade sve poslove zbog manjka ljudskih kapaciteta i financijskih sredstava. Odnosi s javnošću jedna su od najznačajnijih funkcija u poslovanju, međutim, u neprofitnom sektoru potrebne su dodatne edukacije menadžmenta udruga kako bi se odnosi s javnošću implementirali u svakodnevni rad. Rezultati ovog istraživanja djelomično se poklapaju s dobivenim rezultatima provedenog istraživanja Hrvatske udruge za odnose s javnošću i agencije Ipsos Puls o stanju struke odnosa s javnošću u Hrvatskoj - 2013. godine. ${ }^{15}$ Istraživanje je obuhvatilo samo manji dio segmenta odnosa s javnošću u udrugama s invaliditetom. Kako bi se konstruktivno djelovalo na daljnji razvoj odnosa s javnošću u neprofitnom sektoru potrebno je u suradnji s predstavnicima neprofitnog sektora, Hrvatske udruge za odnose s javnošću i eminentnim stručnjacima dogovoriti smjernice za daljnji razvoj. Također, činjenica je da ne postoje detaljna istraživanja u neprofitnom sektoru o stanju struke u Republici Hrvatskoj, potrebna su daljnja istraživanja u području neprofitnog sektora kako bi se promijenila percepcija struke i stručnjaka.

15 Istraživanje dostupno na http://www.huoj.hr/aktivnosti-udruge/provedeno-huoj-evo-istrazivanje-o-stanju-struke-odnosa-sjavnoscu-u-hrvatskoj-2013-hr3759 (27. kolovoza 2020.) 


\section{Literatura}

Alfirević, N., Pavičić, J., Najev Čačija, Lj., Mihanović, Z. i Matković, J. (2013). Osnove marketinga i menadžmenta neprofitnih organizacija. Školska knjiga.

Bežovan, G. (1995). Neprofitne organizacije i kombinirani model socijalne politike. Revija za socijalnu politiku, 3(2), 195-214.

Broom, M.G. (2010). Učinkoviti odnosi s javnošću. Mate d.o.o.

Grbavac, J. i Grbavac, V. (2014). Pojava društvenih mreža kao globalnog komunikacijskog fenomena, Media, culture and public relations, 5(2), 206-219.

Pavičić, J. (2001). Ishodišne determinante strateškog pristupa marketingu neprofitnih organizacija: teorijska razrada, Ekonomski pregled, 52(1-2), 101-124.

Pavičić, J. (2003). Strategija marketinga neprofitnih organizacija. Masmedia.

Puljiz, V. (2006). Socijalna politika i socijalne djelatnosti u Hrvatskoj u razdoblju 1900.-1960. godine, Ljetopis socijalnog rada, 13(1), 7-28.

Radalj, M. (2018). Odnosi s javnošću u neprofitnim organizacijama. Hrvatska sveučilišna naklada; Hrvatska udruga za odnose s javnošću.

Salamon, L. M. i Helmut, K. A. (1992). In Search of the Nonprofit Sector II: The Problem of Classification, Working Papersof the Johns Hopkins Comparative Nonprofit Sector Project, The Johns Hopkins Institute for Policy Studies, 3.

Skoko, B. (2004). Kvantitativni i kvalitativni dosezi odnosa s javnošću u Hrvatskoj 2003., Medijska istraživanja, 1(10), 67-82.

Skoko, B., Jugo, D., Laco, K., Hajoš., B., Španjol Marković, M., Renko, K., Cvetko, S., Škorić, T., Tanta, I., Vlahović, N., Maras Juričić, R., Holy, M. i Kobas Dešković, D. (2009). Odnosi s javnošću za organizacije civilnoga društva. Hrvatska udruga za odnose s javnošću.

Tkalac Verčič, A. (2015). Odnosi s javnošću. Hrvatska udruga za odnose s javnošću.

Tomić. Z. (2016). Odnosi s javnošću teorija i praksa. Synopsis. 
Definicija odnosa s javnošću Međunarodnog udruženja za odnose s javnošću - IPRA, https://www.ipra.org/member-services/pr-definition/

HUOJ istraživanje o stanju struke odnosa s javnošću u Hrvatskoj - 2013.

http://www.huoj.hr/aktivnosti-udruge/provedeno-huoj-evo-istrazivanje-o-stanju-struke-odnosa-sjavnoscu-u-hrvatskoj-2013-hr3759

Internet world stats, http://www.internetworldstats.com/europa.htm\#hr

Pajić, B., Društveni mediji kao marketinški alat,

http://www.scribd.com/doc/142487824/Drustveni-Mediji-Kao-Marketinski-Alat

Registar neprofitnih organizacija, Ministarstvo financija, https://banovac.mfin.hr/rnoprt/

Registar udruga u Republici Hrvatskoj. https://registri.uprava.hr/\#! udruge/MBAAEAAAAA3gQBAAABAgAAAAGA474KAAAAAQEAAAABAgAAAAAAAAABAQFvaeICAfSBBg

Zajednica saveza osoba s invaliditetom Hrvatske - SOIH. http://www.soih.hr/soih-o-nama

Ministarstvo rada i socijalne skrbi (2001). Program borbe protiv siromaštva i isključenosti u Hrvatskoj. https://hrcak.srce.hr/file/47419

Narodne novine (2014). Zakon o udrugama.

https://narodne-novine.nn.hr/clanci/sluzbeni/2014_06 74 1390.html

Narodne novine (2015). Uredba o kriterijima, mjerilima i postupcima financiranja i ugovaranja programa i projekata od interesa za opće dobro koje provode udruge. https://narodne-novine.nn.hr/clanci/sluzbeni/2015 $03 \quad 26 \quad 546 . h t m l$ 


\title{
Public relations in Croatian non-profit organizations based on the example of associations of persons with disabilities
}

\author{
IVANA KUČINA \\ VERN' University, Zagreb \\ KREŠIMIR DABO, PhD \\ Edward Bernays University College, Zagreb
}

\begin{abstract}
The development of socially responsible behavior has been very slow in Croatia. The main goal of non-profit organizations is to come up with solutions for social problems that the government organizations have not detected in a timely manner, while their mission is to provide support to society (mainly marginal groups), enhance humanity and volunteerism and raise public awareness of socially relevant issues. This paper deals with public relations in non-profit organizations based on the example of associations of persons with disabilities. The aim of this paper is to define public relations, non-profit organizations and associations of persons with disabilities in Croatia and to analyze public relations in Croatian associations of persons with disabilities based on the survey. The paper is divided into two parts. The first part gives a theoretical overview of public relations in non-profit organizations, defines associations of persons with disabilities in Croatia and provides a theoretical and legal framework. The second part comprises research that consists of employee attitudes to and opinions about public relations in associations of persons with disabilities and the analysis of data obtained through a survey.
\end{abstract}

Keywords: associations of persons with disabilities, non-profit organization, public relations, media relation 